DOI: https://doi.org/10.32689/2618-0065-2020-2(4)-380-390

Шойко Василь Анатолійович кандидат історичних наук, доцент, заступник начальника інституту - головний інженер Українського науководослідного інституту цивільного захисту, м. Київ, вул. Рибальська, 18, 01011, Україна, тел.: (044)-280-18-01, e-mail.: pom_mtz@ukr.net, https//orcid.org/00000001-8670-8779

\title{
НОРМАТИВНО-ПРАВОВЕ РЕГУЛЮВАННЯ ЦИВІЛЬНОГО ЗАХИСТУ ЩОДО ФОРМУВАННЯ МЕХАНІЗМІВ ДЕРЖАВНОГО УПРАВЛІННЯ У ДАНІЙ СФЕРІ
}

Анотація. У статті проаналізовані особливості вивчення нормативноправового регулювання цивільного захисту щодо формування механізмів державного управління у даній сфері, здійснена оцінка рівня їх дієвості. Визначено, що сучасний стан справ щодо низького рівня ефективності функціонування єдиної державної системи цивільного захисту в Україні має власне історичне коріння. За 28 років історії нашої країни було зафіксовано низку суперечливих дій у напрямі розвитку систем цивільного захисту i, можливо, через це велика кількість проблем накладається одна на одну, а певні структурні проблеми трансформувались у системні.

Визначено, що у 04.10.1932 р. Уряд видав постанову про затвердження Положення про протиповітряну оборону Союзу Радянських Соціалістичних Республік. Прийняття цього акту означало формування місцевої протиповітряної оборони країни, основу майбутньої цивільної оборони. Місцева протиповітряна оборона покликана захищати громадськість від ворожої повітряної атаки. Згідно з Положенням, загальнодержавне керівництво місцевою протиповітряною обороною покладалось на Народний комісаріат оборони, а в регіонах військових округів - на командирів відповідних округів.

Доведено, що важливим кроком у зміцненні місцевої протиповітряної оборони стало затвердження постанови Ради народних комісарів Союзу Радянських Соціалістичних Республік від 20.06 .1937 р. «Про місцеву (цивільну) протиповітряну оборону Москви, Ленінграда, Баку та Києва», яка визначила перелік нових заходів щодо зміцнення місцевої протиповітряної оборони в цих містах.

Визначено три основні типи завдань, які, у 1970 р., постали перед сферою цивільної оборони:

- забезпечення оборони населення;

- підвищення стабільності роботи галузей та підприємств; 
- усунення наслідків використання противником зброї масового ураження, організація та проведення рятувальних та аварійно-відновлювальних робіт у центрах ураження та підготовка сил до їх виконання.

Ключові слова: механізми державного управління, нормативно-правове регулювання цивільного захисту, Постанова Ради праці і оборони «Про організацію повітряно-хімічної оборони території Союзу РСР», Положення про протиповітряну оборону Союзу Радянських Соціалістичних Республік.

Shoyko Vasyl Anatoliyovych Candidate of Historical Sciences, Associate Professor, Deputy Head of the Institute - Chief Engineer of the Ukrainian Research Institute of Civil Protection, Kyiv, st. Rybalska, 18, 01011, Ukraine, tel .: (044) -28018-01, e-mail: pom_mtz@ukr.net, https//orcid.org/0000-0001-8670-8779

\title{
LEGISLATIVE REGULATION OF CIVIL PROTECTION FOR THE FORMATION OF MECHANISMS OF PUBLIC ADMINISTRATION IN THIS SPHERE
}

\begin{abstract}
The article analyzes the peculiarities of studying the legal regulation of civil protection in relation to the formation of mechanisms of public administration in this field, and evaluates the level of their effectiveness. It is determined that the current state of affairs concerning the low level of efficiency of functioning of the single state system of civil protection in Ukraine has its own historical roots. Over the 28 years of our country's history, there have been a number of conflicting actions in the direction of the development of civil protection systems, and perhaps because of this a large number of problems are imposed on each other, and certain structural problems have been transformed into systemic ones.

It was determined that on October 4, 1932, the Government issued a resolution approving the Regulation on air defense of the Union of Soviet Socialist Republics. Adoption of this act meant the formation of local air defense of the country, the basis of future civil defense. Local air defense is designed to protect the public from a hostile air attack. According to the Regulations, the national leadership of local air defense relied on the People's Commissariat of Defense, and in the regions of military districts, on the commanders of the respective districts.

It was proved that an important step in the strengthening of local air defense was the approval of the resolution of the Council of People's Commissars of the Union of Soviet Socialist Republics of 20.06.1937 «On local (civil) air defense of Moscow, Leningrad, Baku and Kiev», which determined the list of changes local air defense in these cities.

There are three main types of tasks that, in 1970, faced the field of civil defense:

- ensuring the protection of the population;

- increase of stability of work of industries and enterprises;
\end{abstract}


- elimination of the consequences of the use of weapons of mass destruction by the enemy, organization and carrying out of rescue and disaster recovery works in the centers of defeat and preparation of forces for their execution.

Keywords: mechanisms of public administration, normative legal regulation of civil protection, Decree of the Labor and Defense Council "On the organization of air-chemical defense of the territory of the USSR Union”, Regulation on the air defense of the Union of Soviet Socialist Republics.

Постановка проблеми. Питання ліквідації надзвичайних ситуацій та зменшення їх негативних наслідків $€$ найактуальнішим та найважливішим для органів державної виконавчої влади, особливо, через постійно зростаючі масштаби наслідків катастроф, аварій та природних катаклізмів.

Однак, наразі, тенденції розвитку сучасного суспільства показують, що діяльність органів державного управління та системи цивільного захисту, результативність заходів щодо протидії катастрофам, аваріям та іншим надзвичайним ситуаціям не постійно відповідають вимогам гарантування необхідного ступеню безпеки людей.

Значні недоліки в організації швидкого реагування на надзвичайні ситуації, у прийнятті оперативних та адекватних рішень, а, також, у проведенні рятувальних та інших невідкладних робіт говорять про низький рівень організації ліквідації надзвичайних ситуацій. Згідно з аналізом, у більшості випадків, ці причини зумовлені відсутністю обгрунтованого досвіду та обізнаності керуючих представників усіх структур управління системою цивільного захисту, а, також, існуючими суперечностями, що лежать в основі нормативно-правових актів галузі цивільного захисту [1].

Аналіз останніх досліджень і публікацій. Аналіз правових напрямів публічного адміністрування, загалом, та в галузі цивільного захисту, зокрема, залишається актуальним в наукових колах фахівців, які провадять дослідження системи державного управління.

О. Гацуля, В. Назаренко [2], О. Соболь, В. Приходько [3], Ф. Рагімов [4] О. Федорчак [5] розглядали істотні аспекти функціонування системи публічного адміністрування у сфері цивільного захисту. Проте, проблеми пошуку шляхів удосконалення державно-правового механізму публічного адміністрування у галузі цивільного захисту лишаються недостатньо дослідженими, оскільки, законодавча база сфери цивільного захисту має недоліки в організації органами публічного адміністрування заходів щодо своєчасного та адекватного реагувань на надзвичайні ситуації [6, с.7].

Формулювання цілей статті. Метою статті $\epsilon$ вивчення нормативноправового регулювання цивільного захисту щодо формування механізмів державного управління у даній сфері, оцінка рівня їх дієвості.

Виклад основного матеріалу дослідження. Загальновідомим є наукове твердження, що виникнення будь-якої системи, значною мірою, встановлює 
напрями іiі подальшого розвитку. Державна вітчизняна система регулювання цивільного захисту, як і подібні системи зарубіжних країн, у цьому значенні не $\epsilon$ винятком.

Сучасний стан справ щодо низького рівня ефективності функціонування єдиної державної системи цивільного захисту в Україні, безумовно, має власне історичне коріння. Адже лише за 28 років історії нашої країни було зафіксовано низку суперечливих дій у напрямі розвитку систем цивільного захисту $\mathrm{i}$, можливо, через це велика кількість проблем накладається одна на одну, а певні структурні проблеми трансформувались у системні [7, с. 172].

Початком формування системи цивільної оброни стала організація оборони Петрограду від повітряних сил Німеччини під час першої світової війни у 1918 р. Важливими аспектами захисту міста стали авіаційні і прожекторні загородження, зенітні батареї, а, також, низка пунктів спостереження. Були створені пункти де видавали протигази, а для жителів встановлювались спеціальні правила поводження при авіаційному нападі.

Починають свою роботу курси надання першої медичної допомоги. У Ленінграді у 1927 р. були організовані курси для підготовки фахівців повітряно-хімічної оборони на базі Військово-хімічного музею. Наступного року такі навчальні заклади почали функціонувати у Баку, Києві, Мінську і Москві [8, с. 19].

Постанова Ради праці і оборони «Про організацію повітряно-хімічної оборони території Союзу РСР» від 14.05.1927 р. встановила заходи, направлені на покращення захисту від можливих авіаційних нападів на стратегічно значущі райони держави: великі промислові міста, заводи, склади, аеродроми, засоби зв’язку, будівлі залізничного та водного транспорту. Територія держави розмежовувалась на прикордонну небезпечну зону та тил [9].

Генеральне керівництво протиповітряною обороною було надано Народному комісаріату з військових та морських справ. Того ж року було прийнято положення про протиповітряну оборону, яке гарантувало захист держави від авіаційних ударів засобами військових та цивільних структур та громадських організацій.

У 1929 р. було створено райони протихімічної оборони: підприємства, які були важливими у військовому та економічному відношеннях, були названі об'єктами протиповітряної оборони, при них були створені штаби протиповітряної оборони. У районах формуються управління протиповітряної оборони, до складу яких входять служби хімічного захисту, внутрішнього нагляду і розвідки, а пізніше - протипожежна, правопорядку, охорони здоров'я , ветеринарна тощо.

Серед жителів формуються організації масової оборони: добровільне об’єднання друзів хімічної оборони та промисловості, об’єднання друзів повітряного флоту [8, с. 20]. 
04.10.1932 р. Уряд видав постанову про затвердження Положення про протиповітряну оборону Союзу Радянських Соціалістичних Республік. Прийняття цього акту означало формування місцевої протиповітряної оборони країни, основу майбутньої цивільної оборони. Місцева протиповітряна оборона покликана захищати громадськість від ворожої повітряної атаки. Згідно 3 Положенням, загальнодержавне керівництво місцевою протиповітряною обороною покладалось на Народний комісаріат оборони, а в регіонах військових округів - на командирів відповідних округів.

Великі міста були пунктами протиповітряної оборони, а найважливіші промислові підприємства, відповідно, - об’єктами. Керівники пунктів протиповітряної оборони призначалися 3 числа командувачів частин протиповітряної оборони армії, а об'єктів протиповітряної оборони - з числа керівників підприємств (організацій, установ) [10, с. 11].

Основні сили для виконання завдань цивільної оборони включали: військові частини місцевої протиповітряної оборони, які підкорялись командуванню військових округів; добровільні формування місцевої протиповітряної оборони: у містах - районні команди, на підприємствах об’єктові групи, при домоуправліннях - групи самооборони [11, с. 276].

Важливим кроком у зміцненні місцевої протиповітряної оборони стало затвердження постанови Ради народних комісарів Союзу Радянських Соціалістичних Республік від 20.06 .1937 р. «Про місцеву (цивільну) протиповітряну оборону Москви, Ленінграда, Баку та Києва», яка визначила перелік нових заходів щодо зміцнення місцевої протиповітряної оборони в цих містах.

У 1961 р. місцева протиповітряна оборона була перетворена на цивільну оборону, яка увійшла до системи загальнодержавних оборонних заходів, що проводяться в мирний та воєнний часи для захисту населення та національної економіки держави від зброї масового знищення та інших видів нападу, а, також, для організації та координації аварійно-рятувальних та інших невідкладних відновлювальних робіт у центрах ураження.

Були сформовані штаби цивільної оборони в усіх союзних, автономних республіках, областях, містах, районах,підприємствах, фабриках, заводах.

У 1970 р. перед цивільною обороною ставились три групи завдань [8, с. 21]:

- забезпечення оборони населення;

- підвищення стабільності роботи галузей та підприємств;

- усунення наслідків використання противником зброї масового ураження, організація та проведення рятувальних та аварійновідновлювальних робіт у центрах ураження та підготовка сил до їх виконання.

Не враховуючи те, що у період 70-80 років XX століття цивільна оборона, в основному, була зосереджена на діях в умовах використання зброї масового ураження, важливе значення мали формування цивільної оборони в боротьбі 3 
надзвичайними природними явищами, промисловими аваріями та катастрофами та під час ліквідації їх результатів (землетруси, пожежі, повені, промислові та транспортні аварії, зливи, аварія на Чорнобильській атомній станції тощо).

Штаби цивільної оборони були робочими органами надзвичайних комісій, їх представники брали участь у розробці i організації підготовчих, профілактичних та інженерних заходів, спрямованих на зниження наслідків стихійних лих та виробничих аварій, особливо, в умовах можливого виникнення значних ризиків, небезпек і загроз у сфері пожежної безпеки.

Разом $з$ тим, технологічна, екологічна та природна ситуації в Україні 3 кожним роком ставали все складнішими, негативний вплив надзвичайних ситуацій на людей та навколишнє середовище постійно збільшувався [8, с. 21]. У зв’язку з цим, постало питання утворення загальнодержавної сфери державного управління цивільною безпекою, разом iз формуванням необхідних органів управління та сил захисту. Вирішення даного завдання було доручено Штабу цивільної оборони України як центральному органу виконавчої влади держави, підпорядкованому Кабінету Міністрів України [12, C. 43].

29 червня 1992 року Уряд затвердив Тимчасове положення про Штаб цивільної оборони України, а 28 жовтня 1992 року - Верховна Рада України схвалила Концепцію Цивільної оборони України.

03 лютого 1993 року був прийнятий Закон України «Про Цивільну оборону України», в якому, вперше, було зафіксовано визначення поняття цивільної оборони України, як державної системи керівних органів управління для реалізації заходів щодо захисту людей від наслідків надзвичайних ситуацій, з урахуванням досвіду економічно розвинутих країн.

Беззаперечним є той факт, що враховуючи накопичений досвід, держава формує систему цивільної оборони, яка має за мету захист населення від загрозливих наслідків аварій і катастроф воєнного, екологічного, природного та техногенного характерів.

Закон України «Про Цивільну оборону України» визначає структуру та склад сфери цивільної оборони України, основні завдання органів управління нею. Також, він конкретизує структуру сил цивільної оборони, систему матеріально-технічного забезпечення заходів у сфері захисту населення, відповідно до міжнародних договорів України, згода на обов’язковість яких надана Верховною Радою України.

Прем’єр-міністр України є начальником Цивільної оборони України, а функціональні обов'язки керівників цивільної оборони на відповідних адміністративно-територіальних одиницях надаються керівникам відповідних органів виконавчої влади [12, с. 43]. 
10 травня 1994 року Постановою Кабінету Міністрів України № 200 було впроваджено «Положення про цивільну оборону України», в якому окреслено основні завдання міністерств та відомств у сфері цивільної оборони.

У процесі вдосконалення нормативно-правового забезпечення діяльності у сфері цивільного захисту, у 1996 році, на основі Штабу цивільної оборони України та Міністерства України у справах захисту населення від наслідків аварії на Чорнобильській атомній електростанції було створено Міністерство України з питань надзвичайних ситуацій та у справах захисту населення від наслідків Чорнобильської катастрофи. Міністерство забезпечує виконання функцій у сфері державного управління галуззю цивільної оборони, здійснює захист населення і територій від надзвичайних ситуацій .

21 серпня 1997 року, згідно з постановою Кабінету Міністрів України [13] Міністерству України з питань надзвичайних ситуацій та у справах захисту населення від наслідків Чорнобильської катастрофи, доручено координацію дій міністерств, центральних і місцевих органів управління у сфері ліквідації наслідків, аварій, катастроф надзвичайних природних явищ.

Разом $з$ тим, за ініціативою Міністерства, у період з 1996 по 2004 рр. Верховна Рада України прийняла ряд законодавчих актів, що належать до сфери цивільної оборони, систематизовані у Таблиці 1.

Таблиия 1

Закони України у сфері цивільної оборони, які були прийнятті у

1996-2004 роках

\begin{tabular}{|c|c|c|}
\hline $\begin{array}{c}\text { Дата } \\
\text { прийняття }\end{array}$ & Назва Закону & Коротка характеристика \\
\hline $\begin{array}{l}24 \text { лютого } \\
1994 \text { року }\end{array}$ & $\begin{array}{l}\text { Закон України «Про } \\
\text { забезпечення } \\
\text { санітарного та } \\
\text { епідеміологічного } \\
\text { благополуччя } \\
\text { населення» }\end{array}$ & 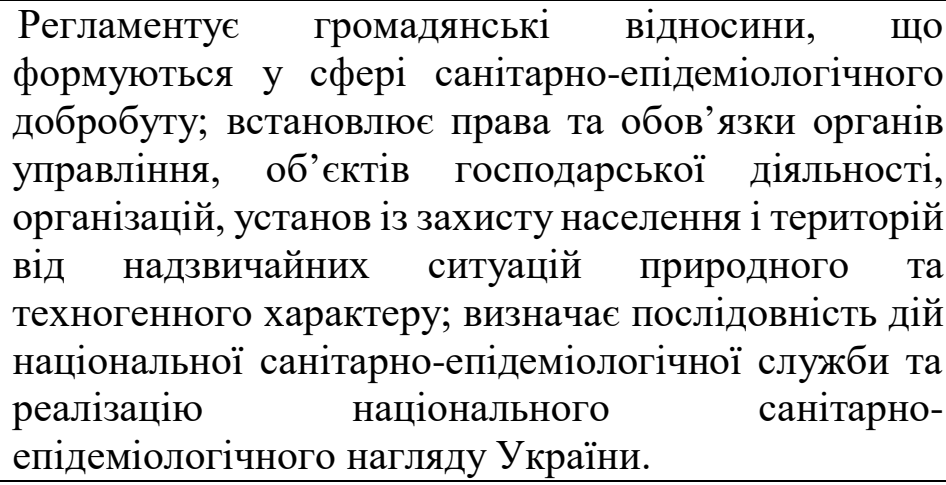 \\
\hline $\begin{array}{l}18 \text { січня } \\
2001 \text { року }\end{array}$ & $\begin{array}{l}\text { Закон України «Про } \\
\text { об’єкти підвищеної } \\
\text { небезпеки» }\end{array}$ & $\begin{array}{l}\text { Визначає теоретичні та практичні засади діяльності, } \\
\text { яка пов’язана з об'єктами підвищеного ризику, а, } \\
\text { також, направлена на оборону життя та здоров'я } \\
\text { населення та навколишнього середовища від } \\
\text { шкідливих наслідків аварій шляхом попередження } \\
\text { їх виникненню, локалізації розгортання та усунення } \\
\text { наслідків. }\end{array}$ \\
\hline
\end{tabular}




\begin{tabular}{|c|c|c|}
\hline $\begin{array}{l}14 \text { січня } \\
1998 \text { року }\end{array}$ & $\begin{array}{l}\text { Закон України «Про } \\
\text { захист людини від } \\
\text { дій } \quad \text { іонізуючих } \\
\text { випромінювань» }\end{array}$ & 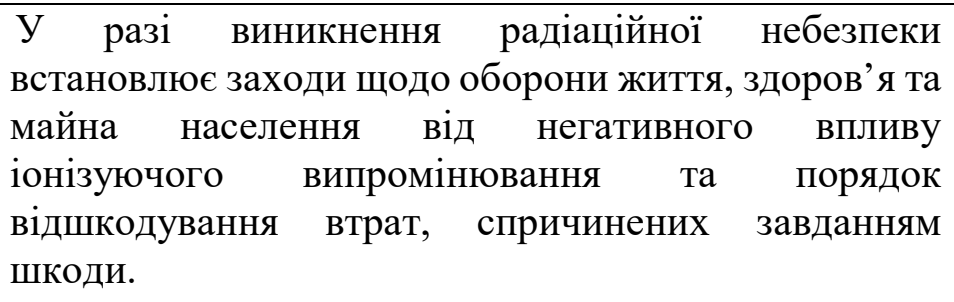 \\
\hline $\begin{array}{l}24 \text { березня } \\
1999 \text { року }\end{array}$ & $\begin{array}{l}\text { Закон України «Про } \\
\text { війська Цивільної } \\
\text { оборони України» }\end{array}$ & $\begin{array}{l}\text { Формулює правові засади та організаційні основи } \\
\text { реалізації функцій військ цивільної оборони } \\
\text { України. }\end{array}$ \\
\hline $\begin{array}{l}14 \text { грудня } \\
1999 \text { року }\end{array}$ & $\begin{array}{l}\text { Закон України «Про } \\
\text { аварійно-рятувальні } \\
\text { служби» }\end{array}$ & $\begin{array}{l}\text { Визначає економічні, організаційні та правові } \\
\text { засади формування та реалізації дій аварійно- } \\
\text { рятувальних служб для громадянського захисту та } \\
\text { вирішення проблем міжнародної взаємодії у напрямі } \\
\text { усунення наслідків надзвичайних ситуацій. }\end{array}$ \\
\hline $\begin{array}{l}06 \text { квітня } \\
2000 \text { року }\end{array}$ & $\begin{array}{l}\text { Закон України «Про } \\
\text { захист населення від } \\
\text { інфекційних хвороб» }\end{array}$ & $\begin{array}{l}\text { Формулює правові, організаційні та фінансові } \\
\text { принципи функціонування органів управління, } \\
\text { місцевого самоврядування, об’єктів господарської } \\
\text { діяльності, організацій та установ, роботи яких } \\
\text { направлена на попередження появи та поширення } \\
\text { інфекційних хвороб населення, а, також, на } \\
\text { локалізацію, ліквідацію спалахів епідемій, визначає } \\
\text { відповідальність осіб в питаннях захисту жителів від } \\
\text { інфекційних захворювань. }\end{array}$ \\
\hline $\begin{array}{l}16 \text { березня } \\
2000 \text { року }\end{array}$ & $\begin{array}{l}\text { Закон України «Про } \\
\text { правовий режим } \\
\text { надзвичайного } \\
\text { стану» }\end{array}$ & $\begin{array}{l}\text { Встановлює правову основу введення режиму } \\
\text { надзвичайного стану, систему його зупинення, } \\
\text { специфіку діяльності органів державної виконавчої } \\
\text { влади та місцевого самоврядування, об'єктів } \\
\text { господарської діяльності, організацій та установ в } \\
\text { надзвичайних ситуаціях для дотримання прав і } \\
\text { свобод особистості та громадянина, а, також формує } \\
\text { відповідальність за недотримання вимог або } \\
\text { порушення правового режиму в умовах } \\
\text { надзвичайних ситуацій. }\end{array}$ \\
\hline $\begin{array}{l}08 \text { червня } \\
2000 \text { року }\end{array}$ & $\begin{array}{l}\text { Закон України «Про } \\
\text { захист населення і } \\
\text { територій } \\
\text { надзвичайних } \\
\text { ситуацій } \\
\text { техногенного } \\
\text { природного } \\
\text { характеру» }\end{array}$ & $\begin{array}{l}\text { Встановлює організаційно-правові засади оборони } \\
\text { громадян України, нерезидентів та осіб без } \\
\text { громадянства, які територіально знаходяться в } \\
\text { Україні. } \\
\text { Закон надає тлумачення основних заходів у галузі } \\
\text { оборони населення та територій, а, також, визначає } \\
\text { фундаментальні основи розбудови та } \\
\text { функціонування єдиної національної структури } \\
\text { органів управління у сфері запобігання та } \\
\text { реагування на надзвичайні ситуації. }\end{array}$ \\
\hline
\end{tabular}


Розглянуті в Табл. 1 законодавчі акти визначили фундамент для переходу від режиму Цивільної оборони до режиму Цивільного захисту в Україні на всіх рівнях $[11 ; 14]$.

Висновок. Отже, у статті було проаналізовано нормативно-правове регулювання цивільного захисту щодо формування механізмів державного управління у даній сфері. Відзначено поступову зростаючу складність технологічної, екологічної та природної ситуацій в Україні, що, з кожним роком, актуалізувала питання утворення загальнодержавної сфери державного управління цивільною безпекою, разом із формуванням необхідних органів управління та сил захисту. Вирішення даного завдання було доручено Штабу цивільної оборони України як центральному органу виконавчої влади держави, підпорядкованому Кабінету Міністрів України.

Зазначено, що у процесі вдосконалення нормативно-правового забезпечення діяльності у сфері цивільного захисту, у 1996 році, на основі Штабу цивільної оборони України та Міністерства України у справах захисту населення від наслідків аварії на Чорнобильській атомній електростанції було створено Міністерство України з питань надзвичайних ситуацій та у справах захисту населення від наслідків Чорнобильської катастрофи. Міністерство забезпечує виконання функцій у сфері державного управління галуззю цивільної оборони, здійснює захист населення і територій від надзвичайних ситуацій.

Проаналізовано ряд законодавчих актів, які визначили фундамент для переходу від режиму Цивільної оборони до режиму Цивільного захисту в Україні на всіх рівнях.

\section{Jimepamypa:}

1. Шойко В.А. Проблеми нормативно-правового забезпечення діяльності органів державного управління в сфері цивільного захисту. Інвестиції: практика та досвід. 2011. №24, 2011, C. 105-107.

2. Назаренко В. Ю. Організаційно-правовий механізм державного управління пожежною безпекою в Україні / Теорія та практика державного управління.- Вип. 3 (42). Режим доступу: http://www.kbuapa.kharkov.ua/e-book/tpdu/2013-3/doc/2/14.pdf

3. Соболь О.М., Приходько Р.В. Організаційно-правовий механізм державного управління у сфері захисту населення і територій від надзвичайних ситуацій / Режим доступу: http://www.kbuapa.kharkov.ua/e-book/db/2012-2/doc/2/13.pdf.

4. Гацуля О., Рагімов Ф. Удосконалення організаційно-правового забезпечення державного управління на регіональному та галузевому рівнях у контексті процесів децентралізації / Державне управління та місцеве самоврядування, 2015, вип. 3(26). С. 101115. - Режим доступу: - http://www.dridu.dp.ua/vidavnictvo/2015/2015_03(26)/13.pdf.

5. Федорчак В. В. Правові засади державного управління моніторингом ризиків виникнення надзвичайних ситуацій в Україні / В. В. Федорчак // Право та державне управління. - 2018. - № 2 (31). - Том 2. - С. 160-163.

6. Бєлікова К.Г., Потеряйко С.П., Удосконалення правового та організаційного механізмів державного управління в сфері цивільного захисту // Всеукраїнська науковопрактична конференція «ПУБЛІЧНЕ УПРАВЛІННЯ ТА АДМІНІСТРУВАННЯ НА СУЧАСНОМУ ЕТАПІ ДЕРЖАВОТВОРЕННЯ» 24 жовтня 2019 року, м. Київ, С.192. 
7. Андреєв С. О. Державні системи цивільного захисту: інституціональні засади та проблеми розвитку : монографія / С. О. Андреєв ; Нац. акад. держ. упр. при Президентові України. - Х. : Тім Пабліш Груп, 2017. - С.432.

8. Васійчук В.О., Гончарук В.С., Качан С.I., Мохняк С.М. Основи цивільного захисту: Навч. посібник / В.О. Васійчук, В.С Гончарук, С.І.Качан, С.М. Мохняк.-Львів: Видавництво Національного університету "Львівська політехніка", 2010.-С.417.

9. Джерело: ДЕПАРТАМЕНТ 3 ПИТАНЬ ЦИВІЛЬНОГО ЗАХИСТУ, ОБОРОННОЇ

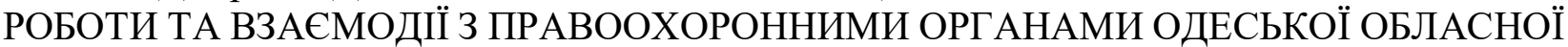
ДЕРЖАВНОЇ АДМІНІСТРАЦІЇ / Історична довідка цивільної оборони http://guns.odessa.gov.ua/storichna-dovdka/

10. Авторський колектив: Бикова О.В., Болієв О.Ч., Деревинський Д.М., Єлісєєв В.Н., Миронець С.М., Осипенко С.І., Півень Ю.О., Плетньов В.І., Попов Л.В., Соколовський І.П. Під редакцією Болотських Михайла Васильовича // УНІВЕРСИТЕТ ЦИВІЛЬНОГО ЗАХИСТУ УКРАЇНИ / ІНСТИТУТ ДЕРЖАВНОГО УПРАВЛІННЯ У СФЕРІ ЦИВІЛЬНОГО ЗАХИСТУ // Посібник Основи цивільного захисту // КИЇВ - 2008, С.181.

11. Плахута В. В. Розвиток державної політики у сфері цивільного захисту України / В. В. Плахута // Гуржіївські історичні читання. - 2011. - Вип. 4. - С. 276-277. - Режим доступу: http://nbuv.gov.ua/j-pdf/gurit_2011_4_129.pdf

12. БОЙКО ОКСАНА СТАНОВЛЕННЯ ДЕРЖАВНОГО УПРАВЛІННЯ У СФЕРІ ЦИВІЛЬНОГО ЗАХИСТУ / Становлення публічного адміністрування в Україні : матеріали Х Конф. студентів та молодих учених за міжнар. участю / за заг. ред. О. Б. Кірєєвої. - Д. : ДРІДУ НАДУ, 2019. - С.354 с.43

13. КАБІНЕТ МІНІСТРІВ УКРАЇНИ П О С Т А Н О В А від 21 серпня 1997 р. N 912 Про Порядок перетинання державного кордону України аварійно-рятувальними та аварійно-відновними формуваннями для локалізації та ліквідації надзвичайних ситуацій, зумовлених стихійним лихом, аваріями і катастрофами Документ 912-97-п, поточна редакція —Редакція від 11.06.2013, https://zakon.rada.gov.ua/laws/show/912-97-\%D0\%BF

14. Романенко Є. О. Державне управління процесами забезпечення внутрішньої екологічної безпеки в Україні: організаційно-правовий аспект / С. О. Романенко // Аспекти публічного управління. - 2016. - № 1-2. - С. 67-73.

\section{References:}

1. Shoiko, V. A. (2011). Problemy normatyvno-pravovoho zabezpechennia diialnosti orhaniv derzhavnoho upravlinnia v sferi tsyvilnoho zakhystu [Problems of regulatory support of the activity of public administration in the field of civil protection]. Investytsii: praktyka ta dosvid - Investment: practice and experience, 24, 105-107 [in Ukrainian].

2. Nazarenko, V. Yu. (2013). Orhanizatsiino-pravovyi mekhanizm derzhavnoho upravlinnia pozhezhnoiu bezpekoiu v Ukraini [Organizational and Legal Mechanism of Public Administration of Fire Safety in Ukraine]. Teoriia ta praktyka derzhavnoho upravlinnia - Theory and Practice of Public Administration, 3(42), 340-347. Retrieved from http://www.kbuapa.kharkov.ua/e-book/tpdu/2013-3/doc/2/14.pdf [in Ukrainian].

3. Sobol, O. M., Prykhodko, R. V. (2012). Orhanizatsiino-pravovyi mekhanizm derzhavnoho upravlinnia u sferi zakhystu naselennia i terytorii vid nadzvychainykh sytuatsii [Organizational and legal mechanism of public administration in the field of protection of population and territories from emergency situations]. Derzhavne budivnytstvo - State Construction, 2. Retrieved from http://www.kbuapa.kharkov.ua/e-book/db/2012-2/doc/2/13.pdf [in Ukrainian].

4. Hatsulia, O., Rahimov, F. (2015). Udoskonalennia orhanizatsiino-pravovoho zabezpechennia derzhavnoho upravlinnia na rehionalnomu ta haluzevomu rivniakh u konteksti protsesiv detsentralizatsii [Improvement of organizational and legal support of public 
administration at the regional and sectoral levels in the context of decentralization processes]. Derzhavne upravlinnia ta mistseve samovriaduvannia - State Administration and Local SelfGovernment, 3(26), 101-115. $\quad$ Retrieved from http://www.dridu.dp.ua/vidavnictvo/2015/2015_03(26)/13.pdf [in Ukrainian].

5. Fedorchak, V. V. (2018). Pravovi zasady derzhavnoho upravlinnia monitorynhom ryzykiv vynyknennia nadzvychainykh sytuatsii $\mathrm{v}$ Ukraini [Legal Principles of Public Administration for Monitoring the Risks of Emergencies in Ukraine]. Pravo ta derzhavne upravlinnia - Law and Public Administration, 2(31), 2, 160-163 [in Ukrainian].

6. Bielikova, K. H., Poteriaiko, S. P. (2019). Udoskonalennia pravovoho ta orhanizatsiinoho mekhanizmiv derzhavnoho upravlinnia v sferi tsyvilnoho zakhystu [Improvement of Legal and Organizational Mechanisms of Public Administration in the Field of Civil Protection]. Publichne upravlinnia ta administruvannia na suchasnomu etapi derzhavotvorennia - Public Administration at the Modern Stage of State Creation : All-Ukrainian Scientific and Practical Conference. (pp. 79). Kyiv [in Ukrainian].

7. Andreiev, S. O. (2017). Derzhavni systemy tsyvilnoho zakhystu: instytutsionalni zasady ta problemy rozvytku [State systems of civil defense: institutional foundations and problems of development]. Kharkiv: Tim Publish Group [in Ukrainian].

8. Vasiichuk, V. O., Honcharuk, V. Ye., Kachan, S. I., Mokhniak, S. M. (2010). Osnovy tsyvilnoho zakhystu [Fundamentals of Civil Protection]. Lviv: Vydavnytstvo Natsionalnoho universytetu "Lvivska politekhnika" [in Ukrainian].

9. Istorychna dovidka tsyvilnoi oborony [Historical background for civil defense]. (n.d.). guns.odessa.gov.ua. Retrieved from http://guns.odessa.gov.ua/storichna-dovdka/ [in Ukrainian].

10. Bykova, O. V., et al. (2008). Osnovy tsyvilnoho zakhystu [Fundamentals of Civil Protection]. M. V. Bolotskykh (Eds.). Kyiv [in Ukrainian].

11. Plakhuta, V. V. (2011). Rozvytok derzhavnoi polityky u sferi tsyvilnoho zakhystu Ukrainy [Development of state policy in the sphere of civil protection of Ukraine]. Hurzhiivski istorychni chytannia - Hurzhiivski historical readings, 4, 276-277. Retrieved from http://nbuv.gov.ua/j-pdf/gurit_2011_4_129.pdf [in Ukrainian].

12. Boiko, O. (2019). Stanovlennia derzhavnoho upravlinnia u sferi tsyvilnoho zakhystu [Establishment of public administration in the field of civil protection]. O. B. Kirieieva (Eds.). Stanovlennia publichnoho administruvannia v Ukraini - Establishment of Public Administration in Ukraine : Proceedings of 10th international conf. for students and young scientists. (pp. 43-45). Dnipro: DRIDU NADU [in Ukrainian].

13. Postanova Kabinetu Ministriv Ukrainy "Pro Poriadok peretynannia derzhavnoho kordonu Ukrainy avariino-riatuvalnymy ta avariino-vidnovnymy formuvanniamy dlia lokalizatsii ta likvidatsii nadzvychainykh sytuatsii, zumovlenykh stykhiinym lykhom, avariiamy i katastrofamy” : vid 21 serpnia 1997 r., № 912 [Decision of the Cabinet of Ministers of Ukraine "On the Procedure of Crossing the State Border of Ukraine by Emergency and Emergency Recovery Formations for Localization and Elimination of Emergencies Caused by Disasters, Accidents and Catastrophes” from August 21, 1997, № 912]. (n.d.). zakon.rada.gov.ua. Retrieved from https://zakon.rada.gov.ua/laws/show/912-97-\%D0\%BF [in Ukrainian].

14. Romanenko, Ye. O. (2016). Derzhavne upravlinnia protsesamy zabezpechennia vnutrishnoi ekolohichnoi bezpeky $\mathrm{v}$ Ukraini: orhanizatsiino-pravovyi aspekt [Public Administration of Internal Environmental Security Processes in Ukraine: Organizational and Legal Aspect]. Aspekty publichnoho upravlinnia - Aspects of Public Management, 1-2, 67-73 [in Ukrainian]. 